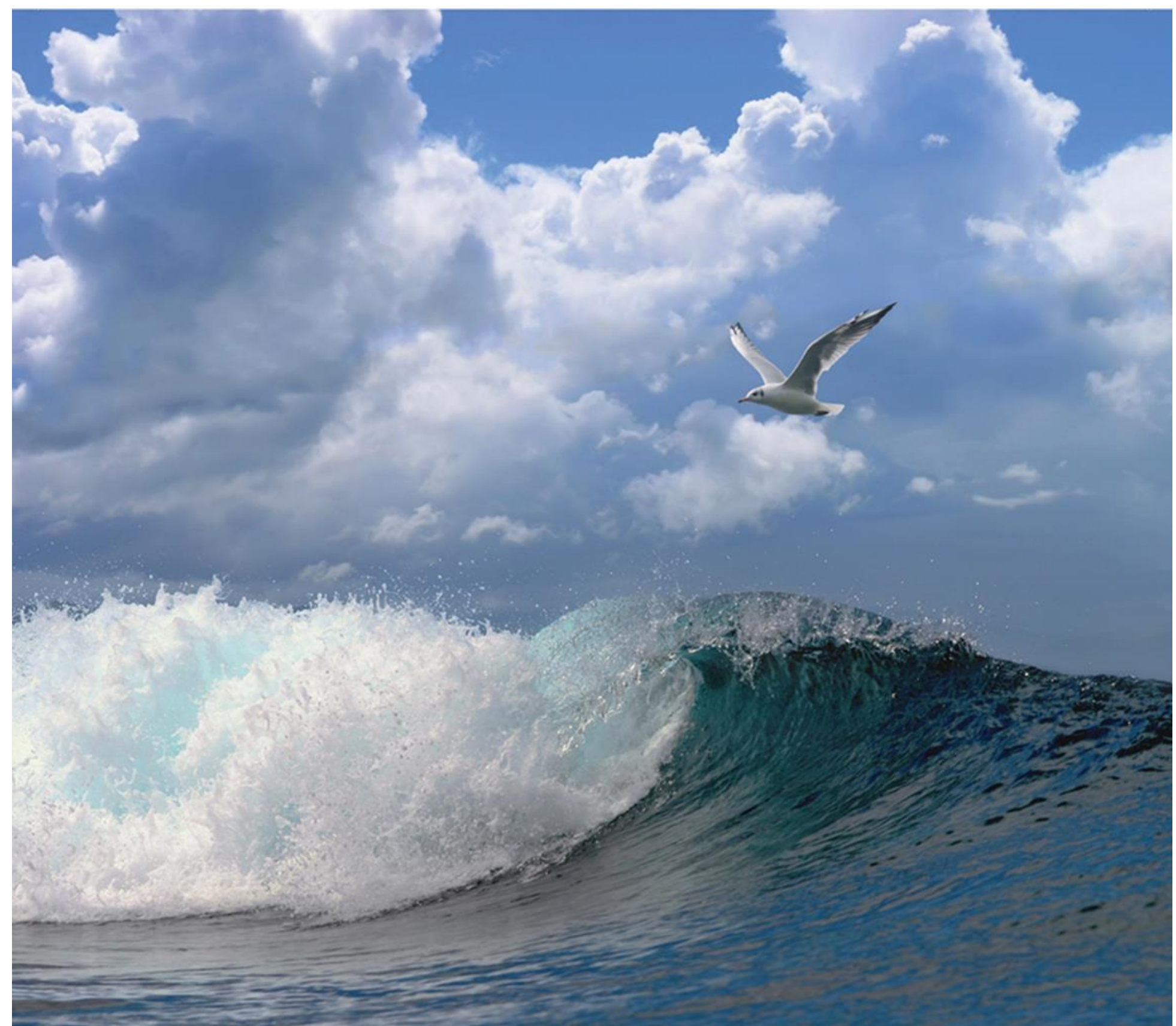

\title{
Data rapportage Marktbemonstering schubvis IJsselmeergebied 2016-2018
}




\section{Data rapportage Marktbemonstering schubvis IJsselmeergebied 2016-2018}

Auteur(s): $\quad$ A.B. Griffioen

Dit onderzoek is uitgevoerd door Wageningen Marine Research in opdracht van en gefinancierd door het Ministerie van Landbouw, Natuur en Voedselkwaliteit, in het kader van het Beleidsondersteunend onderzoekthema 'zoet' (projectnummer BO-43-023.02-002) 
Keywords: schubvis, marktbemonstering, IJsselmeergebied, visserij

Opdrachtgever: Ministerie van Landbouw, Natuur en Voedselkwaliteit

T.a.v.: Mr. Laurent Gorissen

Bezuidenhoutseweg 73

2594 AC Den Haag

Dit rapport is gratis te downloaden van https://doi.org/10.18174/509355

Wageningen Marine Research verstrekt geen gedrukte exemplaren van rapporten.

Wageningen Marine Research is ISO 9001:2015 gecertificeerd.

(C) Wageningen Marine Research

Wageningen Marine Research, instituut binnen de rechtspersoon Stichting

Wageningen Research, hierbij

vertegenwoordigt door Dr. M.C.Th

Scholten, Algemeen directeur

KvK nr. 09098104,

WMR BTW nr. NL 8113.83.696.B16.

Code BIC/SWIFT address: RABONL2U

IBAN code: NL 73 RABO 0373599285
Wageningen Marine Research aanvaardt geen aansprakelijkheid voor gevolgschade, noch voor schade welke voortvloeit uit toepassingen van de resultaten van werkzaamheden of andere gegevens verkregen van Wageningen Marine Research opdrachtgever vrijwaart Wageningen Marine Research van aanspraken van derden in verband met deze toepassing.

Alle rechten voorbehouden. Niets uit deze uitgave mag weergegeven en/of gepubliceerd worden, gefotokopieerd of op enige andere manier gebruikt worden zonder schriftelijke toestemming van de uitgever of auteur. 


\section{Inhoud}

Samenvatting

$1 \quad$ Inleiding

2 Methoden $\quad 6$

3 Resultaten $\quad 7$

$\begin{array}{lll}3.1 & \text { Algemene gegevens } & 7\end{array}$

3.2 Vangstgegevens $\quad 8$

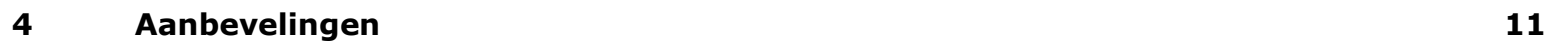

$5 \quad$ Kwaliteitsborging $r 12$

$\begin{array}{lr}\text { Verantwoording } & 13\end{array}$

$\begin{array}{llr}\text { Bijlage } 1 \quad \text { Lengte frequentie gegevens } & 14\end{array}$ 


\section{Samenvatting}

Het ministerie van Landbouw, Natuur en Voedselkwaliteit (LNV) is in het kader van de Visserijwet verantwoordelijk voor een duurzame visserij op snoekbaars, baars, blankvoorn en brasem op het IJsselmeer en Markermeer. Het ministerie heeft hierbij het uitgangspunt het beheer te baseren op wetenschappelijk onderbouwde vangst- en inspanningsadviezen. Ook wil het ministerie meer en betere informatie verzamelen over ontwikkelingen in de leeftijd en lengte opbouw van de vangst en van de bestanden en daarmee toewerken naar nauwkeurigere visserijmodellen.

In 2016 en 2017 zijn eerste pilot studies uitgevoerd. Hierbij zijn beroepsvissers vissend op schubvis (met name baars, brasem, blankvoorn en snoekbaars) bezocht aan boord ten tijde van visserijactiviteiten, welke voornamelijk staand want visserij, maar ook zegenvisserij betrof. Er is besloten om de marktbemonstering voort te zetten in 2018 en 2019. Deze rapportage geeft een overzicht van de gegevens die zijn verzameld in de jaren 2016-2018.

In totaal zijn er in 2016-2018 66 bezoeken geweest bij staandwant en zegen vissers; 14 in 2016 (alleen in kwartaal 3 en 4), 21 in 2017 en 30 in 2018. In totaal zijn 29.531 vissen gemeten aan boord van de schepen. Van de doelsoorten waren dit 6.231 brasem, 9.613 blankvoorn, 4.332 baars en 7.063 snoekbaars. Daarnaast zijn 1.351 bot geteld en gemeten en zijn 17 andere vissoorten gevangen (waaronder steurachtigen en een hybride karper). Daarnaast is ook wolhandkrab en rivierkreeft gevangen.

De gemiddelde lengte van baars was in 2016-2018 respectievelijk 31, 30, 31cm. Hiervan van circa 3$5 \%$ van de vangst ondermaats (kleiner dan $22 \mathrm{~cm}$ ). De gemiddelde lengte van brasem was in 20162018 respectievelijk 32, 33,32cm. De gemiddelde lengte van snoekbaars in 2016-2018 respectievelijk 46, 41, 45cm. Over de jaren 2016-2018 blijkt dat 17-34\% van de vangst van snoekbaarzen kleiner was dan $42 \mathrm{~cm}$ (ondermaats). De gemiddelde lengte van blankvoorn in 2016-2018 respectievelijk 29, 30, $30 \mathrm{~cm}$. Dit zijn vangstgegevens van vissen gevangen in de $101 \mathrm{~mm}$ maas.

De samenwerking met de bezochte beroepsvisserij verliep in 2016 vanuit het perspectief vanuit WMR goed en prettig, ook na herhaald bezoek. In 2017 en 2018 is het merendeel van het veldwerk overgenomen door FISHNED consultancy. Het hebben van een centraal contactpersoon lijkt ook goed te werken voor zowel de beroepsvisserij als voor WMR. De bemonstering wordt voortgezet wordt voortgezet in 2020 . 


\section{$1 \quad$ Inleiding}

Het ministerie van Landbouw, Natuur en Voedselkwaliteit (LNV) is in het kader van de Visserijwet verantwoordelijk voor een duurzame visserij op snoekbaars, baars, blankvoorn en brasem op het IJsselmeer en Markermeer. Het ministerie heeft hierbij het uitgangspunt het beheer te baseren op wetenschappelijk onderbouwde vangst- en inspanningsadviezen. Ook wil het ministerie meer en betere informatie verzamelen over ontwikkelingen in de leeftijd en lengte opbouw van de vangst en van de bestanden en daarmee toewerken naar nauwkeurigere visserijmodellen.

In 2016 en 2017 zijn eerste pilot studies uitgevoerd. Hierbij zijn beroepsvissers vissend op schubvis (met name baars, brasem, blankvoorn en snoekbaars) bezocht aan boord ten tijde van visserijactiviteiten, welke voornamelijk staand want visserij, maar ook zegenvisserij betrof. Er is besloten om de marktbemonstering voort te zetten in 2018 en 2019.

Deze rapportage geeft een overzicht van de gegevens die zijn verzameld in de jaren 2016-2018.

\section{Achtergrond marktbemonstering}

Voor visserijadviezen is informatie over de opbouw van de commerciële vangsten gewenst; welk deel van het bestand wordt gevangen door de visserij? Samen met logboeken (van beroepsvissers) geeft dit een beeld van de jaarlijkse vangsten per leeftijd, wat een essentieel onderdeel is van de visserijmodellen. Ook is voor visserijadviezen informatie nodig over de biologie van een bestand (groei, voortplanting etc.). Deze informatie mist deels voor met name de grotere schubvissen, omdat deze in de wetenschappelijke surveys in lagere aantallen worden aangetroffen. De marktbemonstering voor schubvis is opgezet om gegevens te verzamelen over de samenstelling van de vangst (lengte, leeftijd, gewicht) en het vaststellen van biologische parameters (groei, voortplanting).

\section{Doelstelling}

Het doel van dit onderzoek is:

1. Verzamelen van marktbemonsteringsgegevens van schubvissoorten uit het IJsselmeer en Markermeer over 2016-2018 gedurende veldbezoeken aan boord van vissersschepen.

2. Het analyseren van vismonsters (leeftijd, gewicht, geslacht, rijpheid) 


\section{Methoden}

In 2016 is er gestart met een marktbemonstering schubvis op het IJsselmeer en Markermeer bij staand want vissers en zegenvissers. Het project is opgedeeld in meerdere stappen:

1. Telefonisch benaderen beroepsvissers (van Keeken et al. 2016)

2. Selecteren beroepsvissers op basis van terugkoppeling telefoongesprekken

3. Aanschrijven beroepsvissers middels een enquête om meer detail gegevens te krijgen over visgebied, vangtuig en omvang van de visserij.

4. Selecteren beroepsvissers voor daadwerkelijk bezoek aan boord tijdens visserij activiteit. Daarnaast een herhalingsbrief sturen naar vissers die niet gereageerd hebben.

5. Veldbezoeken (2016-2018)

6. Verwerken gegevens (2016-2018)

7. In 2019 zal een bijeenkomst worden georganiseerd waarin de gegevens aan de deelnemende beroepsvisserij teruggekoppeld wordt.

De veldbezoeken werden verdeeld per kwartaal: Q1 (jan - mrt), Q3 (juli - sept), Q4 (okt - dec). In de marktbemonstering is ervoor gekozen om aan boord te stappen van de vissers. Dit heeft de voorkeur boven het meten of opkopen van vis aan de wal. Enerzijds om een relatie op te bouwen met de beroepsvisserij en anderzijds om goed inzicht te krijgen in de type visserijen. Circa 10-12 bezoeken per kwartaal werden nagestreeft.

\section{Doelsoorten en metingen}

De marktbemonstering heeft vier commerciële doelsoorten voor ogen: snoekbaars, baars, brasem en blankvoorn, waarbij de vissen in Q4 werden opgekocht voor aanvullende metingen (2016 alleen snoekbaars en brasem, in 2017 en 2018 ook baars en blankvoorn). Aan boord werden alle vis, maats, ondermaats en bijvangst opgemeten. Het streven was om, verdeeld over drie kwartalen, minimaal 1000 vissen per soort op te meten en per soort ca. 300 leeftijdsgegevens te verzamelen. Vooralsnog is alleen uit staand want vis verzameld, omdat de zegen voornamelijk levende vis verhandelt.

\section{Lengte metingen}

Metingen aan boord geven een 'totale lengte' aan, waarbij de vis op zijn langst wordt gemeten. Dit betekent dat de staartvin samengeknepen werd om tot een lengte te komen. Hierbij wordt naar de centimeter naar beneden gemeten. Dit houdt bijvoorbeeld in dat $39.9 \mathrm{~cm}$ wordt afgerond naar $39 \mathrm{~cm}$.

\section{Biologische metingen}

Per soort werden ook leeftijd monsters genomen. Dit werd gedaan door 4 á 5 schubben te trekken net boven de zijlijn. Bij baars werden ook vinstralen afgeknipt. Alleen in Q4 werden vissen opgekocht om naast lengte- en leeftijd metingen ook geslacht, rijpheid en gewicht te bepalen. Voor de biologische monsters werden 10 vissen per lengteklasse meegenomen. De lengte klassen waren $2 \mathrm{~cm}$ voor baars en blankvoorn en $3 \mathrm{~cm}$ voor snoekbaars en brasem. 


\section{Resultaten}

\subsection{Algemene gegevens}

\section{Overzicht bezoeken 2016-2018}

In totaal zijn er in 2016-2018 66 bezoeken geweest bij staandwant en zegen vissers; 14 in 2016 (alleen Q3 en Q4) en 21 in 2017 en 30 in 2018 (Tabel 1). In 2017 is er één reis geweest bij een zegenvisser ter oriëntatie ${ }^{1}$, waarbij geen vangstgegevens (lengte gegevens) van deze reis zijn verzameld. Van de reizen waar vangstgegevens van zijn, zijn 59 reizen uitgevoerd met een $101 \mathrm{~mm}$ staand want maaswijdte, vier met 130mm staand want, één met een gecombineerde maaswijdte van 130 en $190 \mathrm{~mm}$ en één zegen reis. In totaal zijn 26 reizen uitgevoerd op het IJsselmeer en 39 op het Markermeer.

Tabel 1. Aantal vaarreizen per vangtuig en per jaar. Tevens een verdeling van het aantal reizen per meer.

\begin{tabular}{|c|c|c|c|c|}
\hline vangtuig (mm) & 2016 & 2017 & \multicolumn{2}{|c|}{2018 totaal } \\
\hline zegen (80) & & (1) & 1 & 1 \\
\hline 101 & 14 & 19 & 26 & 59 \\
\hline 130 & & 1 & 3 & 4 \\
\hline $130 / 190$ & & 1 & & 1 \\
\hline & 2016 & 2017 & 2018 & totaal \\
\hline IJM & 5 & 9 & 12 & 26 \\
\hline $\mathrm{MM}$ & 9 & 12 & 18 & 39 \\
\hline totaal & 14 & 21 & 30 & 65 \\
\hline
\end{tabular}

\footnotetext{
${ }^{1}$ Verkenning voor samenwerking met beroepsvisserij in de zegenvisserij. Vis wordt hier levend verhandeld. De verkenning had als doe om te beoordelen hoe lengte metingen efficiënt gedaan konden worden.
} 


\subsection{Vangstgegevens}

\section{Soorten en aantallen vis}

In totaal zijn 29.531 vissen gemeten aan boord van de schepen (Tabel 2). Van de doelsoorten waren dit 6.231 brasem, 9.613 blankvoorn, 4.332 baars en 7.063 snoekbaars. Daarnaast zijn 1.351 bot geteld en gemeten en zijn 17 andere vissoorten gevangen (waaronder steurachtigen en een hybride karper). Daarnaast is ook wolhandkrab en rivierkreeft gevangen.

Tabel 2. Overzicht van vangstgegevens voor de diverse jaren per meer voor de reizen met van $101 \mathrm{~mm}$ en $130 / 190 \mathrm{~mm}$ staand want en de zegen visserij.

\begin{tabular}{|c|c|c|c|c|c|c|c|c|c|c|c|c|}
\hline \multirow{4}{*}{$\begin{array}{l}\text { locatie } \\
\text { maaswijdte st. wt. of zegen --> } \\
\text { aantal vaartrips }\end{array}$} & \multicolumn{2}{|c|}{2016} & \multicolumn{4}{|c|}{2017} & \multicolumn{4}{|c|}{2018} & \multicolumn{2}{|c|}{ totaal } \\
\hline & IJM & MM & IJM & IJM & MM & MM & IJM & IJM & MM & MM & IJM & MM \\
\hline & 101 & 101 & 101 & 130 & 101 & $130 / 190$ & 101 & 130 & zegen & 101 & & \\
\hline & 5 & 9 & 8 & 1 & 11 & 1 & 9 & 3 & 1 & 17 & 26 & 39 \\
\hline aal & & & & & & & 1 & & & 1 & 1 & 1 \\
\hline amerikaanse rivierkreeften & & 1 & & & & & & & & 3 & 0 & 4 \\
\hline baars & 220 & 469 & 521 & 6 & 1004 & 5 & 648 & 13 & & 1446 & 1408 & 2924 \\
\hline blankvoorn & 337 & 1087 & 603 & & 2247 & 1 & 1308 & 8 & & 4022 & 2256 & 7357 \\
\hline bot & 122 & 11 & 37 & 225 & 113 & 81 & 329 & 296 & & 137 & 1009 & 342 \\
\hline brasem & 712 & 629 & 823 & & 1866 & 182 & 588 & 34 & 74 & 1323 & 2157 & 4074 \\
\hline chinese wolhandkrab & 32 & 2 & 26 & 2 & 39 & & 15 & 4 & & 154 & 79 & 195 \\
\hline gevlekte amerikaanse rivierkreeft & & & & & 1 & & & & & & 0 & 1 \\
\hline giebel & & & & & 5 & & & & & & 0 & 5 \\
\hline houting & 29 & 4 & 10 & 2 & 9 & & 46 & 126 & & 19 & 213 & 32 \\
\hline hybride cyprinide & & 1 & & & 1 & & & & & & 0 & 2 \\
\hline karper & & 1 & & & 4 & & & & & 1 & 0 & 6 \\
\hline kolblei & & 3 & 5 & & 40 & & 3 & & 3 & 3 & 8 & 49 \\
\hline kopvoorn & & & & & 1 & & & & & & 0 & 1 \\
\hline kroeskarper & & & & & & & 1 & & & 9 & 1 & 9 \\
\hline pos & 3 & 17 & 2 & & 11 & & 2 & & & 32 & 7 & 60 \\
\hline roofblei & & 4 & 3 & & 6 & & 1 & & & & 4 & 10 \\
\hline schubkarper & & & & & 1 & & & & & 1 & 0 & 2 \\
\hline snoek & 1 & 4 & 2 & & 15 & 1 & 2 & & 1 & 81 & 5 & 102 \\
\hline snoekbaars & 575 & 575 & 1730 & 33 & 1272 & 32 & 227 & 31 & & 2588 & 2596 & 4467 \\
\hline spiering & 6 & 24 & 26 & & 28 & & 2 & & & 12 & 34 & 64 \\
\hline sterlet & & 1 & & & & & & & & & 0 & 1 \\
\hline steurachtigen & 1 & & & & & & & & & & 1 & 0 \\
\hline winde & 8 & 6 & 2 & & 6 & & 11 & & & 9 & 21 & 21 \\
\hline zwartbekgrondel & 1 & & & & & & & & & 1 & 1 & 1 \\
\hline
\end{tabular}

Omdat er slechts drie reizen zijn uitgevoerd met $130 \mathrm{~mm}$ staand want en één met een zegen (waarvan gegevens bekend zijn), zijn de volgende resultaten gebaseerd op de $101 \mathrm{~mm}$ staand want. 


\section{Lengte frequentie doelsoorten $101 \mathrm{~mm}$ staand want}

Baars

De gemiddelde lengte van baars was in 2016-2018 respectievelijk 31, 30,31cm in de $101 \mathrm{~mm}$ maas (Tabel 3, Figuur 1). Circa 3-5\% van de vangst is ondermaats (kleiner dan $22 \mathrm{~cm}$ ). Dit getal was over de jaren vrijwel gelijk met 4\% in 2016, 3\% in 2017 en 5\% in 2018. De lengterange van de vangst over de drie jaren ligt van circa $4 \mathrm{~cm}$ tot $50 \mathrm{~cm}$. De gemiddelde lengte over de drie jaren op het Markermeer en IJsselmeer was respectievelijk 30 en $31 \mathrm{~cm}$.

\section{Brasem}

De gemiddelde lengte van brasem was in 2016-2018 respectievelijk 32, 33, 32cm in de $101 \mathrm{~mm}$ maas (Tabel 3, Figuur 1). De lengterange van de vangst over de drie jaren lag van circa $20 \mathrm{~cm}$ tot $65 \mathrm{~cm}$. De vangsten laten geen grote verschillen zien in de grootte van de vissen tussen het Markermeer en het IJsselmeer (Figuur 2). De gemiddelde lengte over de drie jaren op het Markermeer en IJsselmeer was respectievelijk 33 en $32 \mathrm{~cm}$.

\section{Snoekbaars}

De gemiddelde lengte van snoekbaars in 2016-2018 respectievelijk 46, 41, 45cm in de $101 \mathrm{~mm}$ maas (Tabel 3, Figuur 1). De lengte range van de vangst over de drie jaren ligt van circa $7 \mathrm{~cm}$ tot een lengte van $75 \mathrm{~cm} .17-34 \%$ van de vangst van snoekbaarzen was kleiner dan $42 \mathrm{~cm}$. Dit getal fluctueert over de jaren met $17 \%$ in $2016,34 \%$ in 2017 en $22 \%$ in 2018. De vangsten laten geen grote verschillen zien in de grootte van de vissen tussen het Markermeer en het IJsselmeer (Figuur 2). De gemiddelde lengte over de drie jaren op het Markermeer en IJsselmeer was respectievelijk 44 en $42 \mathrm{~cm}$.

\section{Blankvoorn}

De gemiddelde lengte van blankvoorn in 2016-2018 respectievelijk 29, 30, 30 cm in de $101 \mathrm{~mm}$ maas (Tabel 3, Figuur 1). De lengterange van de vangst over de drie jaren lag van $17 \mathrm{~cm}$ tot $44 \mathrm{~cm}$ (Figuur 2). De gemiddelde lengte over de drie jaren op het Markermeer en IJsselmeer was respectievelijk 30 en $31 \mathrm{~cm}$.

Tabel 3. Vangstgegevens van baars, brasem, snoekbaars en blankvoorn in de jaren 2016-2018 met aantallen, aandeel 'marktwaardig' $(\%)$, gemiddelde lengte $(\mathrm{cm})$, minimale lengte $(\mathrm{cm})$, maximale lengte $(\mathrm{cm})$.

\begin{tabular}{|c|c|c|c|c|c|c|c|c|c|c|c|c|c|c|c|c|}
\hline & \multicolumn{5}{|c|}{2016} & \multicolumn{5}{|c|}{2017} & \multicolumn{5}{|c|}{2018} \\
\hline & & $\mathrm{n}$ & $\%$ & $\operatorname{avg}(\mathrm{cm})$ & $\min (\mathrm{cm})$ & $\max (\mathrm{cm})$ & & $\%$ & $\operatorname{avg}(\mathrm{cm})$ & $\min (\mathrm{cm})$ & $\max (\mathrm{cm}) \mathrm{r}$ & $\mathrm{n}$ & $\%$ & $\operatorname{avg}(\mathrm{cm})$ & $\min (\mathrm{cm})$ & $\max (\mathrm{cm})$ \\
\hline baars & $<22 \mathrm{~cm}$ & 28 & $4.06 \%$ & & & & 49 & $3.19 \%$ & & & & 95 & $4.51 \%$ & & & \\
\hline brasem & & & & 31.80 & 22 & 54 & & & 32.68 & 20 & 65 & & & 31.65 & 16 & 64 \\
\hline snoekbaars & & 1150 & & 45.81 & 12 & 65 & 3067 & & 40.48 & 15 & 72 & 2846 & & 45.35 & 7 & 75 \\
\hline snoekbaars & $<42 \mathrm{~cm}$ & 194 & $16.87 \%$ & & & & 1033 & $33.68 \%$ & & & & 613 & $21.54 \%$ & & & \\
\hline snoekbaars > & $>42 \mathrm{~cm}$ & 956 & $83.13 \%$ & & & & 2034 & $66.32 \%$ & & & & 2233 & $78.46 \%$ & & & \\
\hline
\end{tabular}



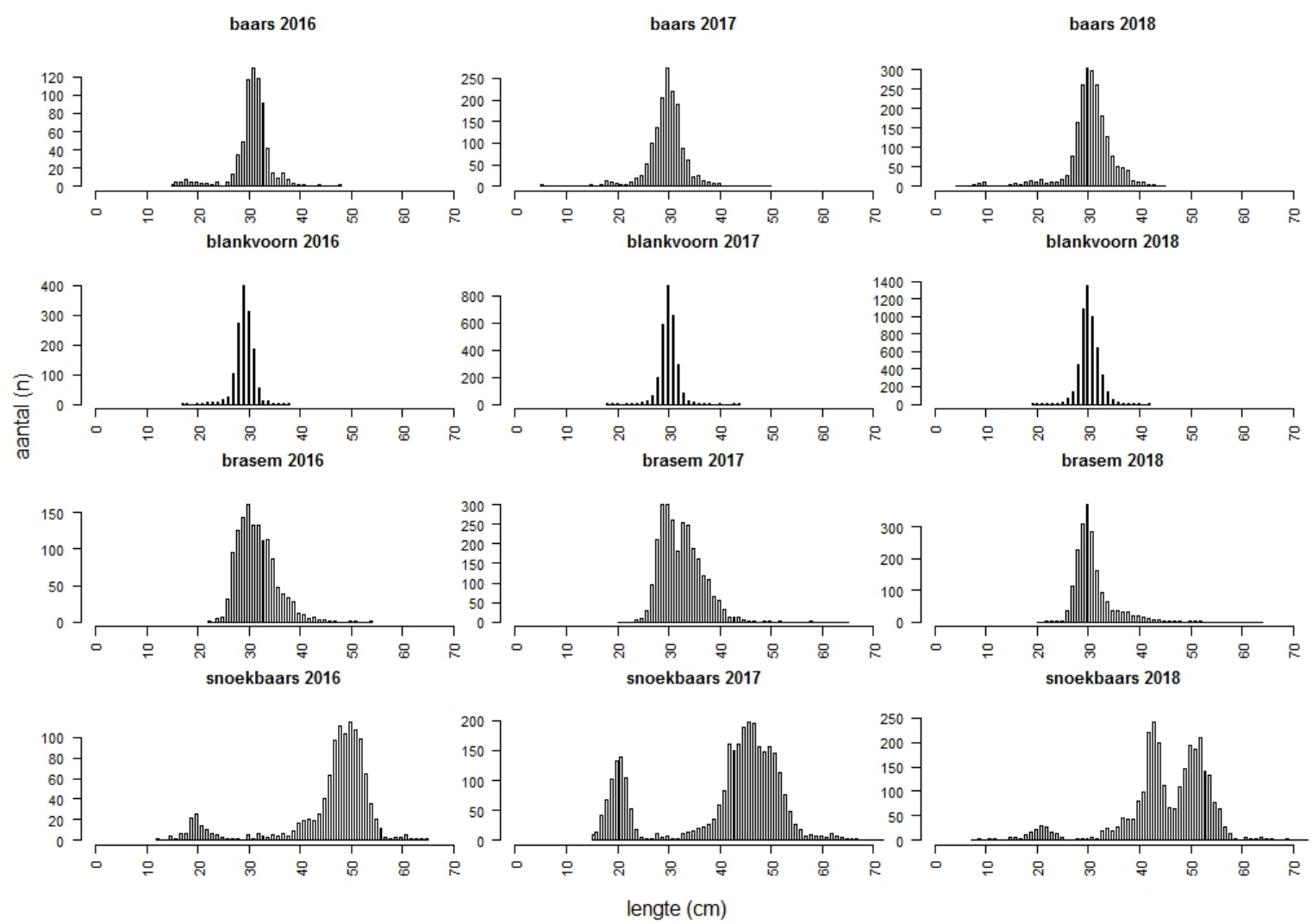

Figuur 1 lengte frequentie figuren per soort per jaar.

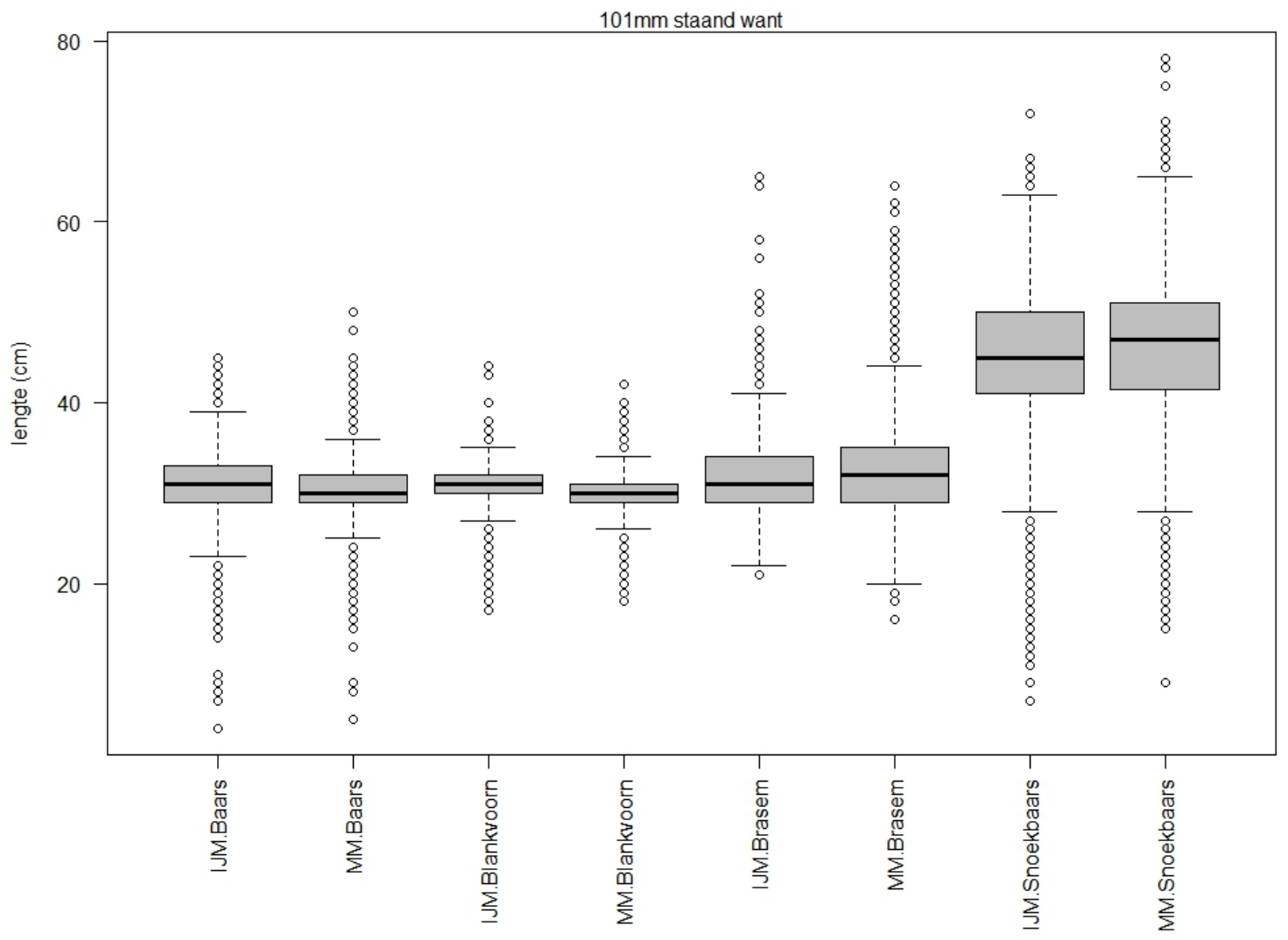

locatie en soort (MM=Markermeer, IJM=IJsselmeer)

Figuur 2 lengte verdeling van vangst per meer en per soort. 


\section{$4 \quad$ Aanbevelingen}

\section{Terugkoppeling samenwerking vissers en aanbevelingen}

De samenwerking met de bezochte beroepsvisserij verliep in 2016 vanuit het perspectief vanuit WMR goed en prettig, ook na herhaald bezoek. In 2017 en 2018 is het merendeel van het veldwerk overgenomen door FISHNED consultancy. Het hebben van een centraal contactpersoon lijkt ook goed te werken voor zowel de beroepsvisserij als voor WMR.

\section{Vergoeding visserij en aanbevelingen}

De vissers ontvingen een vergoeding per vaartrip voor hun medewerking dat WMR of FISHNED medewerkers hun vangsten mochten opmeten aan boord. Indien vissen werden opgekocht (baars, blankvoorn, brasem en snoekbaars), waren de prijzen hoger dan de marktwaarde. Hiervoor is bewust gekozen. Binnen dit project was de voorkeur uitgesproken voor een daadwerkelijk bezoek aan boord boven het (alleen) meten van vis aan de wal. Volgende jaren kan er mogelijk een combinatie worden gezocht waarbij zowel vis van de markt wordt gekocht, als aan boord. Dit zou een betere inzicht geven in het aandeel vis wat overboord wordt gezet.

In de praktijk blijkt dat er soms problemen zijn bij de afronding van de betaling in verband met de voorwaarden die worden gesteld met opstellen van facturen. Een vertragend proces in betalingen werkt niet goed mee in de samenwerking tussen beroepsvisserij en WMR. Hiervoor wordt voorgesteld om de betaling aan de beroepsvisserij via FISHNED te laten lopen, waardoor de lijnen tussen beroepsvisserij en de uitvoerende partij (FISHNED) kort blijven.

\section{Leeftijd gegevens en andere biologische kenmerken.}

In de praktijk is het gebleken dat er nog onvoldoende vissen worden verzameld om aan de 10 exemplaren per lengteklasse te komen voor biologische gegevens. Om deze reden is ervoor gekozen om de vissen die moeten worden verzameld aan te vullen met de "staand want survey" die WMR uitvoert in samenwerking met beroepsvisserij. Deze survey gebruikt staand want bestaande uit panelen met verschillende maaswijdtes. Gedurende deze survey is gebleken dat relatief eenvoudig meerdere lengteklassen kunnen worden verzameld en uiteindelijk verwerkt. Tevens wordt ook ondermaatse vis gevangen. De marktbemonstering en de surveys op het IJsselmeer en Markermeer verzamelen dan gezamenlijk vis van zo veel mogelijk lengteklassen. Hiervoor is het noodzakelijk dat er een duidelijke communicatie tussen WMR en FISHNED moet plaatsvinden voor het verzamelen van vis. Omdat de survey een onderzoek betreft, zal dit onder een dierproefvergunning moeten plaatsvinden. Middels deze vergunning kan men ook ondermaatse vis meenemen voor analyse. Tevens is het voor een goed beeld van de vangstsamenstelling ook aan te raden om voor de leeftijdgegevens ook buiten Q4 vis te verzamelen. 


\section{$5 \quad$ Kwaliteitsborging}

Wageningen Marine Research beschikt over een ISO 9001:2015 gecertificeerd kwaliteitsmanagementsysteem. Dit certificaat is geldig tot 15 december 2021. De organisatie is gecertificeerd sinds 27 februari 2001. De certificering is uitgevoerd door DNV GL.

Het chemisch laboratorium te IJmuiden beschikt over een EN-ISO/IEC 17025:2017 accreditatie voor testlaboratoria met nummer L097. Deze accreditatie is geldig tot 1 april 2021 en is voor het eerst verleend op 27 maart 1997; deze accreditatie is verleend door de Raad voor Accreditatie. Het chemisch laboratorium heeft hierdoor aangetoond in staat te zijn op technisch bekwame wijze valide resultaten te leveren en te werken volgens de ISO17025 norm. De scope (L097) met de geaccrediteerde analysemethoden is te vinden op de website van de Raad voor Accreditatie (www.rva.nl).

Op grond van deze accreditatie is het kwaliteitskenmerk $\mathrm{Q}$ toegekend aan de resultaten van die componenten die op de scope staan vermeld, mits aan alle kwaliteitseisen is voldaan. Het kwaliteitskenmerk Q staat vermeld in de tabellen met de onderzoeksresultaten. Indien het kwaliteitskenmerk $Q$ niet staat vermeld is de reden hiervan vermeld.

De kwaliteit van de analysemethoden wordt op verschillende manieren gewaarborgd. De juistheid van de analysemethoden wordt regelmatig getoetst door deelname aan ringonderzoeken waaronder die georganiseerd door QUASIMEME. Indien geen ringonderzoek voorhanden is, wordt een tweede lijnscontrole uitgevoerd. Tevens wordt bij iedere meetserie een eerstelijnscontrole uitgevoerd. Naast de lijnscontroles wordende volgende algemene kwaliteitscontroles uitgevoerd:

- Blanco onderzoek.

- Terugvinding (recovery).

- $\quad$ Interne standaard voor borging opwerkmethode.

- Injectie standard.

- Gevoeligheid.

Bovenstaande controles staan beschreven in Wageningen Marine Research werkvoorschrift ISW 2.10.2.105.

Indien gewenst kunnen gegevens met betrekking tot de prestatiekenmerken van de analysemethoden bij het chemisch laboratorium worden opgevraagd.

Indien sprake is van onbeheerste kwaliteit worden passende maatregelen genomen. 


\section{Verantwoording}

Rapport C130/19

Projectnummer: 4318100284

Dit rapport is met grote zorgvuldigheid tot stand gekomen. De wetenschappelijke kwaliteit is intern getoetst door een collega-onderzoeker en het verantwoordelijk lid van het managementteam van Wageningen Marine Research

Akkoord

Ir. O.A. van Keeken

Onderzoeker

Handtekening:

Datum:

19 december 2019

Akkoord:

Dr.Ir. T.P. Bult

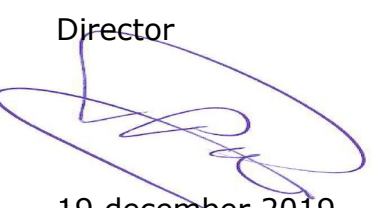

Handtekening:

Datum:

19 december 2019 


\section{Bijlage 1 Lengte frequentie gegevens}
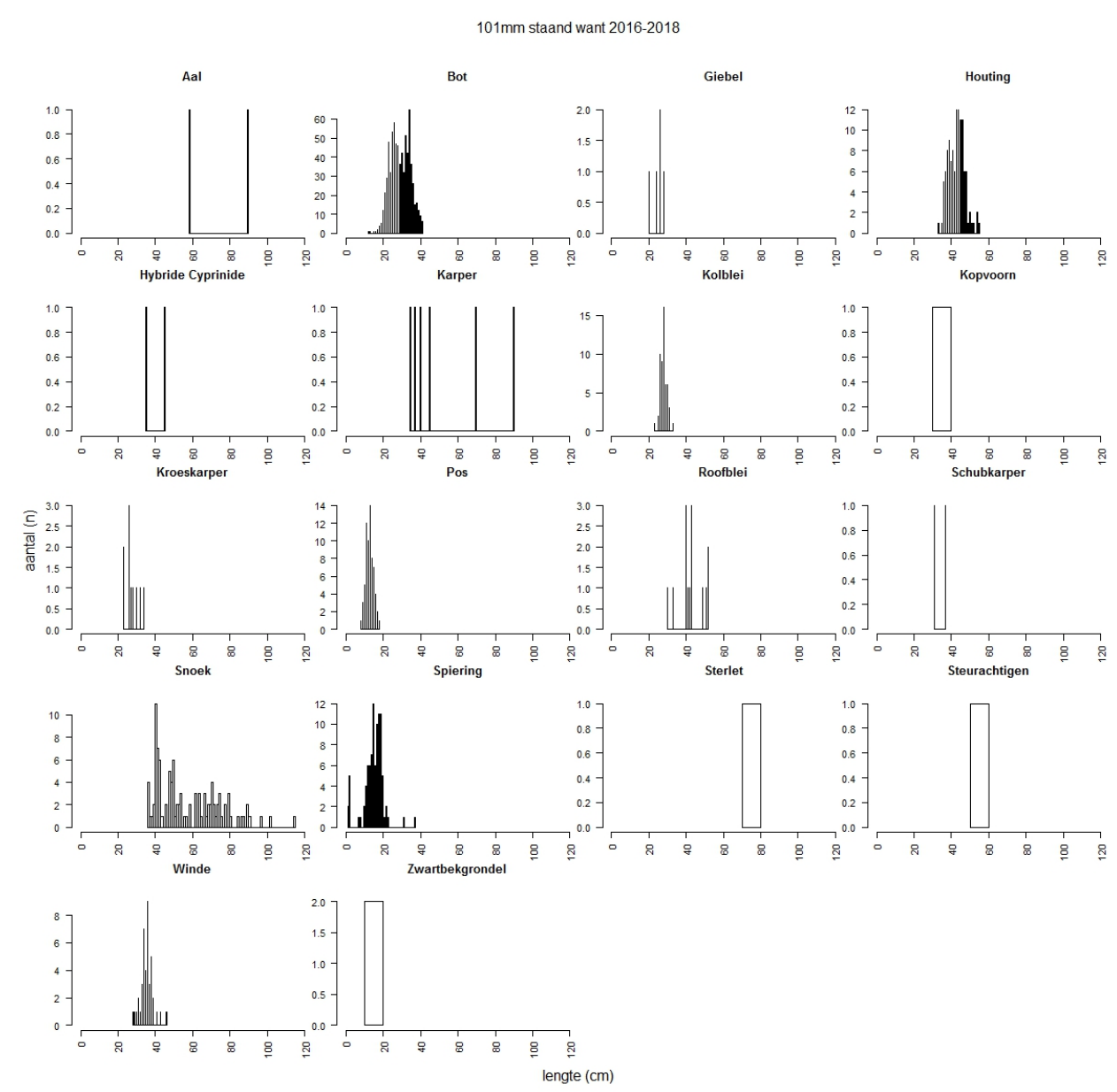

130-190mm staand want
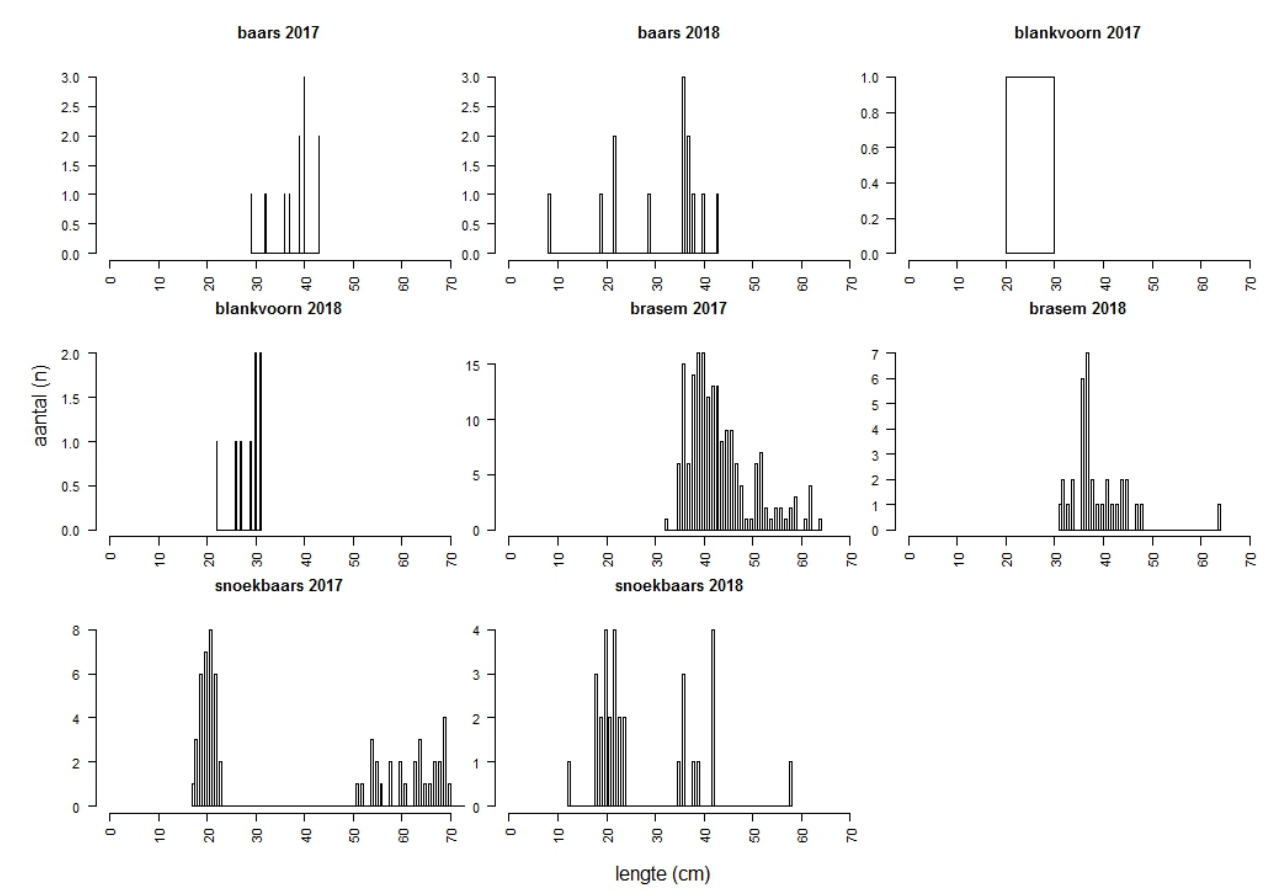
zegen

brasem 2018

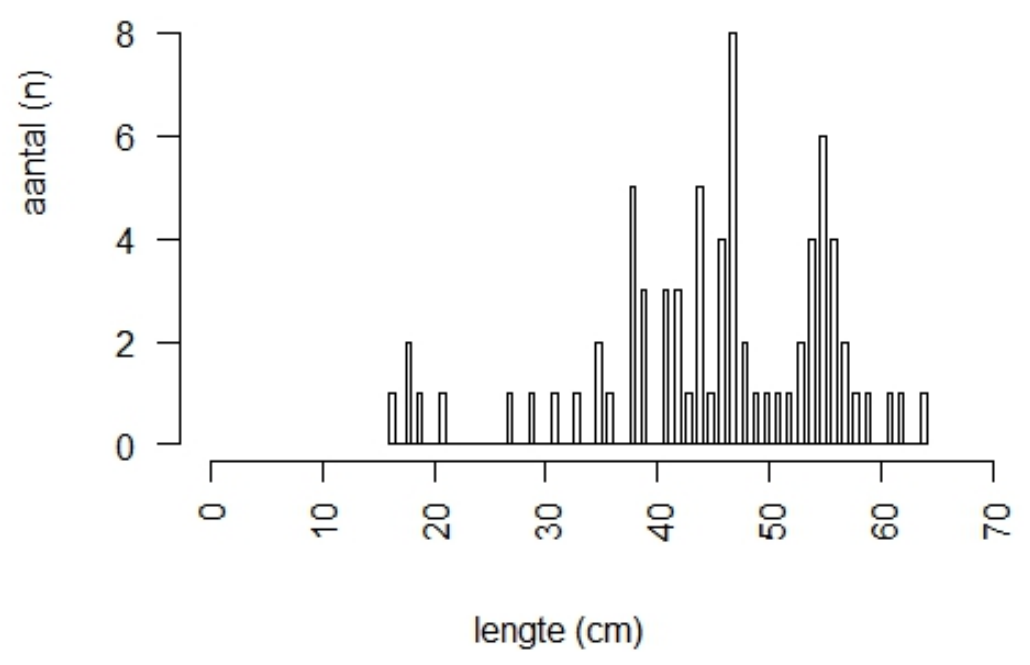


Wageningen Marine Research

$\mathrm{T}:+31(0) 317480900$

E: marine-research@wur.nl

www.wur.nl/marine-research

Bezoekers adres:

- Ankerpark 271781 AG Den Helder

- Korringaweg 7, 4401 NT Yerseke

- Haringkade 1, 1976 CP IJmuiden
Wageningen Marine Research levert met kennis, onafhankelijk wetenschappelijk onderzoek en advies een wezenlijke bijdrage aan een duurzamer, zorgvuldiger beheer, gebruik en bescherming van de natuurlijke rijkdommen in zee-, kust- en zoetwatergebieden.
Wageningen Marine Research is onderdeel van Wageningen University \& Research. Wageningen University \& Research is het samenwerkingsverband tussen Wageningen University en Stichting Wageningen Research en heeft als missie: 'To explore the potential of nature to improve the quality of life' 